Gamze Ülker Tümlü ${ }^{1}$

Ramazan Akdoğan $2^{*}$

Ayşe Sibel Türküm ${ }^{3}$

\section{The Process of Group Counseling Based on Reality Therapy Applied to the Parents of Children with Disabilities}

Abstract

The aim of this study was to use a Reality Therapy approach to identify the psychological difficulties and the psychological support requirements of the parents of children with disabilities and to develop a group counseling program with a group to meet these requirements, and then to experimentally assess the effect of the program on the hopelessness, and state and trait anxiety levels of the parents and their perceptions of social support. A total of 32 parents of children with disabilities voluntarily participated in the study, comprising 27 females and 5 males. The study consisted of 2 stages, the first of which was applied as semi-structured interviews within the framework of qualitative research. On a theoretical basis and the findings obtained from the interviews were developed into the Reality Therapy-Based Group Counseling Program (RTGCP). In the second stage of the study, the effect on dependent variables of the RTGCP was tested with a $2 \times 2$ design on 20 female volunteers from the 32 participants. The findings showed that the RTGCP had a statistically significant effect on the increase in multiple perceptions of social support $(z=-2.67 ; p<0.05)$ and the decrease in state anxiety levels $(U=16.00 ; p<0.05)$.

Keywords: Parents of children with disabilities, Reality Therapy, Choice Theory, Basic psychological needs

\section{Introduction}

Parenting a child with disability is extremely challenging and is a source of stress, which can continue sometimes even throughout life, depending on the nature of the disability. Just as the presence of a child with disability affects the parents personally, it is a traumatic event which also affects relationships within and outside the family of all the family members (Taanila, Syrjala, Kokkonen, \& Jarvelin, 2002). On the one hand, these are problems that are experienced personally and on the other hand, the marital relationships with spouses are affected and there is a decrease in life satisfaction (Şimşek, Tascı, \& Karabulut, 2015, Soltani, Afshari, \& Bahredar, 2016). Some authors have suggested that parents who have brought a child with disability into the world go into a grieving process and explain the experiences of parents on the basis of the Kübler-Ross (1969) model of grieving (Witcher, 1987). According to this, the difficult experiences of the parents start with the diagnosis of the child and theoretically end with acceptance (Witcher, 1987). In contrast, other studies have shown that parents experience many long-term problems such as burnout (Duran \& Barlas, 2014), depression (Harrison \& Stuifbergen, 2002),

\footnotetext{
${ }^{1}$ Res. Ast., Anadolu University, Faculty of Education, Department of Educational Sciences, Program in Guidance and Psychological Counseling, Eskişehir, TURKEY.

${ }^{2} \mathrm{Ph}$. D., Anadolu University, Research Institute for Individuals with Disabilities, Eskișehir, TURKEY.

* Corresponding Author

e-mail: rakdogan@anadolu.edu.tr

${ }^{3}$ Ph.D., Prof., Anadolu University, Faculty of Education, Department of Educational Sciences, Program in Guidance and Psychological Counseling, Eskişehir, TURKEY

International Journal of Early Childhood Special Education (INT-JECSE), 9(2) - 2017, 81-98.
} 
anxiety (Coşkun \& Akkaş, 2009), hopelessness (Çatalbaş, Manav, \& Ocakçı, 2015) and stress (Hung, Wu, \& Yeh, 2004; Norizan \& Shamsuddin, 2010) both at the stage of diagnosis and long after diagnosis. In this context, some authors have suggested that very few parents reach the stage of acceptance and the process of adapting to a child with disability continues throughout life (Akdoğan, 2016; Veisson, 1999). However many theoretical explanations and researchers have claimed that parents have accepted this situation within a process (Case, 2000; Fortier \& Wanlass, 1987; Sen \& Yurtsever, 2007; Witcher, 1987), but in reality, many parents never accept that they have a child with disability, and a significant proportion of the psychological problems experienced originate from this (Akdoğan, 2016; Gibson, 1995).

The acceptance of a child with disability is related in one aspect to the ability of the parent to effectively deal with the disability. Therefore, it can be extremely important to have objective information about the disability (Akkök, 1994), or acquire the necessary strategic skills to deal with behavioural problems of the child (Kroeger and Sorensen, 2010). However, when the psychological difficulties are taken into consideration, the realisation of parents of their own basic needs with the reality of having a child with disability can be said to be related to the decisions made on the way to meet these. Without doubt, it is not the choice of any individual to have a child with disability, but it is their own choice to recognise and meet their own basic needs within the process of effectively dealing with the actual situation. At this point, it seems that Reality Therapy, and Choice Theory which is the foundation of this therapy approach, could be an effective approach for the parents of children with disabilities to support healthy decision-making by accepting the situation. Choice Theory asserts that there are always better choices for individuals to be able to better control their lives and that they should learn to put these into practice. Thus, the approach emphasises acceptance of reality and the importance of being able to make choices despite this reality (Glasser, 2005; Wubbolding, 2010).

Choice Theory and the psychological requirements of the parents of children with disabilities
According to Reality Therapy, there is an indisputable and objective "real world" on which everyone agrees (Glasser, 1998). For example, when this is examined in respect of a parent of an child with autism, there is a reality on which everyone can agree, which is that the parent has a child with autism and there are specific reactions to the nature of autism. There is, however, a world that is based on subjective perception, which is the only reality for the individual (Powers, 1973). Similarly, the feeling of shame within society of the parent related to problem behaviours of the child with autism can cause a withdrawal from the social environment and this creates a subjective reality based on subjective perception. According to Powers (1973), behaviours exhibited by an individual are formed in the framework of perceptions of the subjective world, fed more by the need to control that reality rather than the real world. In this context it is important for individuals to enter their phenomenonological world to be able to understand their needs and the form of their perceived reality to be able to provide mananagement of their choices. According to Choice Theory, a person has five basic needs from birth, which are survival, love and a sense of belonging, success and power reflecting self-confidence and selfrespect, fun, and freedom, and their very nature requires that there is a constant search to satisfy these needs (Glasser, 2000; Glasser, 2004; Sharf, 2012; Wubbolding, 2000; Wubbolding, 2010). These needs, which are the source of behaviours, are general and universal. The ways to meet these needs, which are specific to all individuals, can show differences from person to person. Despite all the challenging conditions, people meet these needs by making choices and finding their own specific behaviours (Wubbolding, 2000). With the most general statement of the theory, being happy leads to meeting the needs in question (Glasser, 2000).

One of the most important psychological difficulties faced by the parents of a child with disability is the burnout created by the responsibility for the child and this responsibility distances the parents from their own needs (Akdoğan, 2016). Without doubt, the existence of the child with disability is an unavoidable and undesired reality. The perception of this reality by the parents affects 
the taking on of responsibility and the meeting of their own personal needs. In fact, the responsibility related to the child is included in almost all of the daily life of the parent and creates a barrier to meeting the personal needs of the parent (Akdoğan, 2016; Trigonaki, 2002). Despite this reality, in the light of the specifications of Reality Therapy, it seems to be possible to both take responsibility and meet personal needs as a personal choice. Furthermore, people are typically searching for what they want in reality and what behaviour choices are required to fulfill this (Soltani, Afshari, \& Bahredar, 2016). Reality Therapy is based on helping people to make better choices to deal with responsibility in life and meet their needs (Wubbolding, 2011). In other words, although reality cannot be changed, it is possible to change the form of perception of reality and to make better choices within this reality and thus to be freer. Similarly, although it is not possible for an individual to control everything that is happening, there are still things which can be controlled. According to Glasser (2000), the only thing that can be controlled by an individual is oneself, in other words, feelings, thoughts and behaviours. Despite all the difficulties in life, an individual can find a way to be able to make their own decisions and to be able to make themselves happy. On the other hand, individuals can complain quite rightfully, that life is not fair. There are no guarantees that life is fair and the only guarantee that is recognised and can be changed by the individual is the person themself (Corey, 2015). When a person believes that they have the power to control their own decisions, they will feel stronger and more autonomous and will be able to take the opportunities to realise themselves (Ivey, Ivey, Myers, \& Sweeney, 2013).

According to Glasser, love and a sense of belonging is a basic need because most people need others to be able to meet their needs (Sommers-Flanagan \& SommersFlanagan, 2015). In this context, it can be said that one of the important needs faced by parents of a child with disability is related to the need for love and a feeling of belonging. Previous studies conducted on the families of children with disabilities have shown that the psychological difficulties associated with a child with disability, on the one hand create a barrier to the establishment of social and emotional relationships, which damage the love links within the family of a child with disability (Akdoğan, 2016; Trigonaki, 2002) and on the other hand lead to social exclusion and stigmatisation resulting in perceptions by the family themselves that they are different and outside the community (Jahoda \& Markova, 2004; Zibricky, 2014). Reality Therapy on this point is found in functional predictions. According to this, most of the problems experienced originate from not establishing a satisfying and successful relationship with at least one significant person in the individual's life. The theory is oriented towards directing the client to significant relationships for themselves in the therapeutic process, making real choices that affect their personal relationships, and teaching a more effective form of behaviour than the pre-existing behaviour (Corey, 2015). In the therapeutic process, psychology consultants are assisted by clients making plans to recognise their own behaviours, to evaluate these and to make changes. The awareness of the forms of relationships with others allows individuals to be autonomous and self-fulfilled (Ivey, Ivey, Myers, \& Sweeney, 2013). Consequently, the aim in Reality Therapy is for individuals to develop more satisfying relationships and to be happy by gaining a feeling of internal control over their life (Wubbolding, 2011).

By benefitting from sources of social support, an individual with an awareness of the forms of their relationships can find the chance to meet their basic needs. The need for social support of the group in question revealed by previous studies of the parents of children with disabilities suggests that the five basic needs of the parents can be met through sources of social support (Boyd, 2002; Karadağ, 2009; Weiss, 2002). Parents who view social support positively also have the opportunity to receive feedback on their parenting skills. While parents who are praised and encouraged by others feel more worthy and that they have "good parenting skills", those evaluated as emotionally weak feel unworthy and unhappy (Trigonaki, 2002). For example, the mother of a child developmentally retarded can make time for herself by sometimes leaving the child with a close friend, and could meet the need for love and the feeling of belonging by experiencing the feeling of being a person who can obtain this support and be 
more free as an individual. It can be understood from the example, that by meeting the need for social support, the individual could also have the opportunity to meet the need for fun.

Being in relationships with other people and having an effective role on others in relationships serves to meet the need of individuals for power. According to Glasser (1998), by having others do what you say, showing them that you are right, and obtaining even more by punishing them when they have done "wrong", meets the need of individuals for power. On the other hand, doing good for others when in a relationship, or taking them into consideration and wanting to be understood may also meet the need for power (Glasser, 1998). People with a child with disability often experience misunderstandings and can be faced with various emotional problems in explaining the form of the child's disability to family and friends (Karadağ, 2009). They may feel particularly powerless in the process of meeting the child's educational needs (Trigonaki, 2002). This situation may cause an impediment to meeting the need for love and a sense of belonging and to the need for power. Judgement of the parents of a child with disability, particularly the mother, as personally successful or unsuccessful can cause the mother to be blamed by those around her as the mother of an unhealthy or "unsuccessful" child and she can even feel humiliated. The responses of a father to having a child with disability are directly affected by the mother's emotions and he may be confronted by maternal anxiety and feelings of hopelessness (Doğru \& Arslan, 2006). Even though the father of a child with disability may sometimes blame himself, he can also blame his wife for the child's disability (Trigonaki, 2002). In this situation, individuals feel under pressure and when the needs for freedom and power cannot be met, this causes hopelessness and anxiety in their lives. There are studies in this area that have shown that the parents of children with disabilities have high levels of hopelessness (Çatalbaş, Manav, \& Ocakçı, 2015; Danış, 2006) and anxiety (Coşkun \& Akkaş, 2009; Üskün \& Gündoğar, 2010).

\section{Current Study}

The starting point of this study was the prediction that a significant proportion of the difficulties faced by the parents of children with disabilities could be connected with the fulfillment of the basic needs as suggested in Reality Therapy. In other words, it was hypothesised that the hopelessness (Çatalbaş, Manav \& Ocakçı, 2015; Danış, 2006), anxiety (Coşkun \& Akkaş, 2009; Üskün \& Gündoğar, 2010) and perception of low social support (Boyd, 2002; Karadağ, 2009; Weiss, 2002) frequently experienced by the parents of children with disabilities were triggered by the non-fulfillment of basic needs. In parallel with the theoretical specifications of having a child with disability, the needs of the parents in respect of love and a feeling of belonging, power, freedom, fun and survival were predicted to be prevented and it was hypothesised that recommendations arising from the feedback of the application of Reality Therapy could be effective in meeting those needs. With an appropriate attitude of the counselor in the process of help based on Reality Therapy, clients will more effectively acquire a view directed to meeting their needs of internal satisfaction related to love and feeling of belonging, power and self-worth, freedom and fun (Wubbolding, Brickell, Imhof, Inza Kim, Lojk, \& Al-Rashidi, 2004). This viewpoint acquired by parents is expected to decrease levels of anxiety and hopelessness and increase perceptions of social support. In this context, the aim of this study was to identify the difficulties experienced by parents in the light of the specifications of Reality Therapy and again in the framework of the theory, to reduce levels of hopelessness and anxiety and increase social support perceptions which are encountered in the struggle to deal with these difficulties.

This study was conducted in two stages. First, the parents of children with disabilities were questioned about problems originating from having a child with a disability, as described in the specifications of Reality Therapy. After the development of a group counseling program, a group provided feedback to deal with the problems that emerged and it was aimed to examine the effect of the program on the hopelessness, and state and trait anxiety levels and on the perceived level of social support of the parents. The research conducted is explained in detail under the headings of Study I and Study II given below.

International Journal of Early Childhood Special Education (INT-JECSE), 9(2) - 2017, 81-98. 
Study I

\section{Method}

This stage of the study was constructed in accordance with qualitative research design. Through semi-structured interviews, the perceptions of the parents of children with disabilities in respect of their psychological needs were revealed and inductive analysis was applied to the data obtained (Cresswell, 2012). From the data obtained, a Psychological Support Requirement Identification Form (PSRIF) for use in the second stage of the study and a group counseling program with a semi-structured group were developed by the researchers under the heading of the Reality TherapyBased Group Counseling Program (RTGCP).

\section{Participants}

This stage of the study was conducted in the 2014-15 academic year at the Research Institute for Individuals with Disabilities at Anadolu University with 32 parents of children with disabilities who were receiving special educational support. The volunteer parents comprised 27 mothers and 5 fathers in the age range of 24-51 years. The diagnoses of the children were autism in 7 cases, Down's Syndrome in 11 cases and developmental retardation in 14 cases. Of the parents, 5 had a single child, 15 had 2 children, 7 had 3 children and 5 had 4 children. None of the participants had another child with a disability. The occupations of the participants were reported as 22 housewives, 3 teachers, 2 civil servants, 1 research assistant, 1 lawyer, 1 police officer, 1 nurse and 1 chemist.

\section{Data collection tools}

Semi-structured Interview Form (SSIF): The SSIF is a form containing open-ended questions, which were formed from the relevant responses and experiences of counseling applied to individuals and groups with theoretical explanations related to Reality Therapy, applied by the second author who conducted group counseling with the parents of children with disabilities who were receiving education at the Research Institute for Individuals with Disabilities of Anadolu University. During the interviews, when it was seen to be necessary, analytical questions were asked in addition to the questions on the form in order to obtain more detail. The questions on the form are given below.

- What do you experience because your child has a disability?

- What are the differences between your life before having a child with disability and your life now?

- What would you do differently now if you did not have a child with disability?

- What do you experience in your relationships (spouse, friends, relatives) related to your child's disability?

- How are you on the subject of making time for youself as an individual?

- What can you say about your expectations for the future?

\section{Data collection process and analysis}

Approval for the study was granted by the Research Institute for Individuals with Disabilities of Anadolu University. Informed consent was given by all the participants. Semistructured interview techniques were used in the context of a qualitative approach and in this framework, individual face-to-face interviews were conducted with 32 volunteer parents. All the interviews with the participants were conducted by the first author in a private interview room. The interviews were recorded, or in cases where the participants did not want an audio recording, notes were taken during and after the interview. Each interview session lasted approximately 15 mins. In the analysis process, the responses of the parents were first analysed thematically without any interpretation. Then the researchers studied the same materials and themes were created by coding the responses of the parents. Inductive analysis was used in the theming process, and the participants were coded sequentially as P1 - P32. Following this stage, the researchers discussed the responses of each participant and main themes were identified.

\section{Results}

The results related to the content of the psychological needs of the parents of children with disabilities are presented in this 
section. Explanations are then given related to the development and application of the RTGCP, which was developed in the light of these findings.

\section{Findings related to the psychological needs} of the parents of children with disabilities

The results of the inductive analysis showed that the needs of power, love and the feeling of belonging, fun, freedom, and survival of the parents of children with disabilities were in parallel with the specifications in Reality Therapy, and the problems they experienced could be evaluated under these themes. The themes obtained from the interviews, the codes related to the themes and summaries of statements of the participants are presented in Table 1.

\section{The development and application of the RTGCP}

The RTGCP was developed with the aid of the theoretical data related to Reality Therapy, the findings of the semi-structured interviews and expert opinions. The interview data were consistent with the hypotheses related to the Reality Therapy psychological needs of the parents and showed that the parents experienced difficulties in meeting their basic needs of survival, freedom, fun, love and a sense of belonging, and power. In this context, care was taken to construct the program to be developed in a form appropriate to these data. A program was formed which consisted of 8 sessions. In addition to the general group counseling principles of unconditional acceptance, unconditional respect, empathy and transparency, the RTGCP also took into consideration the principles related to group counseling in $\mathrm{Re}$ ality Therapy. The process, which is formed on the basis of a positive and safe relationship with a psychology councellor, was planned to be followed up with the WDEP stages as described by Wubbolding (2011). Accordingly, the cycle of Wants, Doing/Direction, Self-Evaluation and Planning was taken as the basis in the process of group counseling. On these foundations, the RTGCP was discussed and the final form of the program was reached. Group counseling was applied as the RTGCP to the experiment group for a period of 8 weeks and no program was applied to the control group. The program with the same leader (the first author of this study) was monitored throughout the 8 weeks. Each session lasted approximately 90 mins. The audio recordings of the sessions, which were made with the permission of the participants, were documented in writing each week by the first author, and these written records were presented to the second and third authors each week for supervision. The sessions were also reviewed weekly in group supervision consisting of 5 doctorate students and 3 assistant supervisors under the leadership of the third author.

In Reality Therapy applied in the process of counseling, the relationship between the client and the counsellor is important. The relationship between therapeutic compliance and counseling is established by the counsellor listening, having empathy with and believing in the potential of the client. Reality therapists provide clients with feelings of safety and hope for the future. When the counselor has this attitude, the clients have a more effective perspective towards meeting their needs for internal satisfaction related to love and a feeling of belonging, power/ self-worth, freedom and fun (Wubbolding et al, 2004). Effective Reality Therapy means the establishment of a safe, warm relationship. Therefore, from the beginning, the process was planned as a process based on a safe and warm group environment. By starting from the formation of a safe and warm group environment, it was aimed for the participants to recognise their psychological needs and to recognise and evaluate the internal conversation and basic beliefs of behaviours oriented to meeting these needs, and following the selfevaluations, to plan for new behaviours.

According to the stages of WDEP, the whole process is undertaken in the course of "what do you want?" in the context of wants, "what have you done to reach this goal and how have you done it?" in the context of doing/direction, "how beneficial has what you have done been?" in the context of self-evaluation, and "what else can you do differently? in the context of planning. It is predicted in Reality Therapy that the individuals will see that it was not their choice to have a child with disability and will focus on what they can do to make life with the child meaningful. The process was managed from the starting point of the experiences based on the data obtained in the semi- 
structured interviews and from the group process. It emerged that the participants had basic needs of love and a feeling of belonging, power, fun, survival and freedom, and particularly because of the "cultural" responsibility of having a child with disability, they experienced difficulties in meeting those needs.

\section{Table 1.}

Themes and codes related to the psychological needs of the parents

\begin{tabular}{|c|c|}
\hline Themes & Codes \\
\hline The need for power & $\begin{array}{l}\text { Feeling weak and powerless, feeling the need to appear strong, } \\
\text { feeling defensive within the community, avoiding going to busy } \\
\text { places, avoiding asking for help, struggling with the child alone }\end{array}$ \\
\hline \multicolumn{2}{|c|}{$\begin{array}{l}\text { "I don't go to busy, crowded places as my child doesn't listen to me and runs around, shouting, so I } \\
\text { may be humiliated together with my child" (P3) } \\
\text { "I think I can deal with it on my own. I don't take help from anvone else. Generally I do this" (P20) }\end{array}$} \\
\hline The need for fun & $\begin{array}{l}\text { Making time for oneself, spending time with friends, sharing private } \\
\text { moments with your spouse, avoiding going to public places }\end{array}$ \\
\hline
\end{tabular}

"I can't make time for myself, because apart from having a child with disability. I don't have the chance to even say that I can have a Saturday to myself. I'm not sure if it's because my child is disabled, but even if he weren't and my only work were my job, I still wouldn't be able to make time for myself. It would be good if I could but it doesn't seem to be possible" (P15)

"I have friends from university that I was very close to and we used to meet up all the time, but since my child was born we haven't been able to see each other properly". (P12).

The need for love and a sense of belonging
Being misunderstood by spouse, mother, father, mother-in-law, father-in-law and friends, not wanting to have guests at home, feeling sad about weak links with neighbours, friends and relatives, not sharing private moments with spouse, feeling guilty

"My mother, my own mother, could not accept this situation at all. Not in any way. She always claims that there is nothing wrong with my child, saying, "look you're wasting your time, since this child was born you've been tiring yourself out, and look, in the end there will be nothing wrong", and this makes me very tired. Even from the person closest to me, my mother, I am treated like this." (P9)

"I've given up work now which I didn't want to, as in response to even a small complaint from me my husband immediately says'what have you been doing all day when I go to work?'. I'm doing this willingly now and l've left work, but for example if I'm sweeping the floor and trying to move an armchair my husband never gets up from where he's sitting and says 'leave it, I'll move it'. What l'm trying to say is that he knows that I want him to understand that I'm tired, he should understand without me asking for help. I need help, I need him" (P4).

The need for freedom

Feeling entrapped, life is child-centred, avoiding using public transport, avoiding crowded public places, feeling that you can't breathe, feeling guilty when you do make time for yourself

"I've completely changed my life. For the last 6 months, my dream of having a career from the years at university and the effort l've made, has been put on hold. I hope that everything will get back on track soon and I can carry on with everything, but maybe I'm throwing it all away, I don't know how and I don't know where, but l've come to the point where l've changed everything in my life, material, spiritual, all aspects of my life." (P18)

"For example, coming here today, half of me is still at home to watch over my child because I always have to warn him to be careful, so he's on my mind now. Even though he's not a little child." (P20)

"Time passes so quickly and I'm so busy and sometimes l'm suffocated by it and feel as if I can't breathe. You struggle and you struggle and you're rushing about until evening and at the end of the day, it's as if it wasn't you doing it and then the next day is just the same. I'm trapped." (P3)

The need for survival Worrying about the future for your child if anything should happen to culties, not eating well, not sleeping well 


\begin{abstract}
"I worry about who would look after my child if anything happened to me... What will happen to our children after us? My only concern is that my daughter may be left alone who will support her? That's my worry (P5)

"Believe me, I can't even remember what l've eaten during the day and at the end of the day my only concern is whether my child is hungry or not." (P31)
\end{abstract}

In line with theoretical specifications, efforts were made to encourage the participants to change their awareness into behaviour. Thus, it was observed that the participants in the group process gained awareness of their feelings, thoughts and behaviours, transferred their awareness of their gains to their lives and made time for themselves to do this. Furthermore, the vast majority of the participants stated that within the process they had been able to develop skills to establish empathy with their spouse and other people close to them and to make use of sources of social support by asking for help. Participants who thought they were of no use, focussed on what they could do differently when events occurred and the making of plans for different situations allowed them to meet their needs. In other words, the process of group counseling provided developments in awareness which can be expressed as a metaphor using the airline safety instructions, "attach your own oxygen mask before that of your child". Some of the statements made by the participants after the group counseling process are given below:

"What we shared here was what we've experienced and I explained to my husband a little bit of how I felt and especially situations that made me feel upset.... When I spoke about it here I noticed that really in the end when I'm talking about my sadness, why do I seem weak, and what happens if I seem weak? In the end there is my husband. That I even thought that seems ridiculous to me now" (P3).

“...especially after our conversations here, I made an evaluation like this. You have to say that you cannot be aware of my thoughts and feelings at the moment and you can't know what I think until I tell you. But what I have done is to say nothing and to think that he understands everything" (P18).

“...we used to argue when he didn't understand me and when I'm expressing myself directly from anger, that doesn't solve the problem. In the group, when I changed my attitude when expressing my disappointment at the time I was upset, I saw the effect of expressing myself on my husband (P5).

“...instead of expecting to be misunderstood, I started trying to explain myself. I saw that angry outbursts were of no benefit to anybody and that I was damaged more ...I didn't know before that I needed something like this, it was only when I came here that I realised. I saw that people like me were experiencing the same things (P20).

"Yes, in the same way, although l've sometimes met people like me because we've been at the Institute because of our children, this has been different because of the psychological perspective of sharing things and now I am more peaceful and think how to spend my time more effectively. So yes, I can say I have reached my goal and I'm more comfortable now" (P4).

“...I felt a need for freedom, and just like others, a need for love and to be loved and so I want to establish empathy and that way, everything will work out. I want to take steps to meet my needs by trying to understand the other person's needs." (P5)

"I've understood that there are situations in life that we can control and there are situations that are not in our control and so rather than thinking that we could do something to control our child's diagnosis, we could do something to develop our child..." (P31)

At the end of the study, individual counseling was applied to those individuals who could not particpate in the group sessions for whatever reasons. 
Study II

\section{Method}

At this stage of the research, it was aimed to examine the effect of the developed RTGCP on the hopelessness, and state and trait anxiety levels and perceptions of social support of the parents. An experimental design of $2 \times 2$ (pre-test-post-test, study and control groups) was used in the study.

\section{Participants}

The study was conducted with 18 parents, comprising 9 in the experiment group and 9 in the control group. The parents were selected from those who had benefitted from the group counseling and been personally interviewed in the first stage of the study. Before the study, the 9 individuals were assigned to the experiment group and the other 9 individuals as the control group were assigned to a waiting list and were informed that they would receive group counseling at the end of the study. Then the participants were assigned to the study and control groups taking into consideration the points obtained in the measurement scales. As a result of the Mann Whitney $U$ analysis, no significant difference was determined between the groups.

\section{Data collection tools}

Beck Hopelessness Scale (BHS): BHS is a scale of 20 items in 3 sub-dimensions (feelings related to future, motivation loss and future expectations) which aims to measure the level of hopelessness felt by individuals for the future. It was originally developed by Beck, Weissman, Lester, and Trexler (1974) and adapted to Turkish culture by Seber (1991) and Durak (1993). The participants were requested to read each item and mark each one as "true" (1 point) or "false" ( 0 point). Higher total points obtained indicated a higher level of hopelessness (Seber, 1991). The Cronbach's alpha coefficient of the original form of the scale was calculated as 0.93 , and the item-total correlations were found to be between 0.39 and 0.76 (Beck et al, 1974). In the reliability analysis of the adapted form of the scale, the Cronbach alpha value was calculated as 0.85 and the item-total correlations were found to be between 0.31 and 0.67 (Durak, 1993).

State and Trait Anxiety Inventory (STAl): The original STAI was developed by Gorsuch and Lushene (1970) to measure anxiety levels in adolescents aged $\geq 14$ years, students, patients and healthy adults. It was later adapted to Turkish by Öner and Le Compte (1998) as a 40-item, 4-point Likerttype scale where 1=no, 2=a little, 3=a lot and $4=$ completely. It consists of two subdimensions with 20 items in each; Trait Anxiety Inventory (TAI) and State Anxiety Inventory (SAI). High scale points indicate high levels of anxiety. In reliability analyses, the Cronbach alpha internal reliability coefficient was found to be $0.83-0.87$ for the TAl and $0.94-0.96$ for the SAI. The test repeatability reliability coefficients were found to range from 0.71 to 0.86 for the TAl and from 0.26 to 0.68 for the SAl (Öner and Le Compte, 1998).

The Multidimentional Scale of Perceived Social Support (MSPSS): MSPSS is a 5-point Likert-type scale, which was originally developed by Zimet, Dahlem, Zimet and Farley (1988) to measure subjectively assessed social support. The scale was later adapted to Turkish culture by Eker \& Arkar (1995). The scale aims to measure the perception of the individual of social support related to family, friends and other significant people and it consists of 3 subscales, each with 4 items. Each item is rated on a 5-point Likert-type scale ranging from strongly disagree (1 point) to strongly agree (5 points) and high points indicate a high perception of social support (Zimet, et al., 1988). The Cronbach's alpha and test-retest reliability values of the original scale were calculated as 0.88 and 0.85 respectively (Zimet, et al., 1988). In the adaptation to Turkish study the Cronbach's alpha value was calculated as 0.87 , which supported the cross-cultural stability of the factor structure of the MSPSS (Eker \& Arkar, 1995). All the points of the scale were used in this study.

Psychological Support Requirement Identification Form (PSRIF): Following the individual semi-structured interviews which were conducted by the researchers to determine the psychological needs of the parents, the 
PSRIF was developed in the relevant theoretical framework, with the themes obtained and in the light of expert opinions. Accordingly, the PSRIF was created with a total of 12 items corresponding to the psychological requirements of the parents of children with disabilities, in the context of the basic needs of love and a feeling of belonging, power, freedom, survival and fun as predicted in Choice Theory. The form was prepared as a checklist with a 10-point Likert-type response ranging from $1=$ always to $10=$ never. The participants were requested to read each item and grade the problem related to having a child with disability. With this grading, it was aimed to identify the areas of the individual requiring psychological support. In the experimental application in Study II, pre-test and post-test was used as one of the data collection tools for the findings of the items on this form.

\section{Statistical Analysis}

To statistically evaluate the effect of the RTGCP on dependent variables, the Mann Whitney $U$ test was used in comparisons between the groups and the Wilcoxon Signed Rank test in within-group comparisons. The PSRIF was used for subjective evaluation of the effectiveness of the program in meeting the needs of the participants. In the evaluation of the PSRIF, the results were stated as number $(n)$ and percentage $(\%)$.

\section{Results}

In this section, the findings are presented of the comparisons of the mean points between the study and control groups in the pre-tests and post-tests related to the BHS, TAI, SAI and MPSS variables, the results obtained from the comparisons within the groups of the mean points of the same variables, and the findings related to the PSRIF in the pre-test and post-test comparisons between the groups and within the groups.

\section{Findings obtained from comparisons} between the groups

The pre-test measurements of the BHS, TAI, SAI, and MSPSS scales were those taken from the experiment group and control group participants before the experiment and the post-test measurements were those taken after the experiment. Descriptive statistics related to the mean points obtained from the groups in the pre-test and post-test evaluations are shown in Table 2.

Table 2.

Mean points and standard deviations(SD) obtained pre-test and post-test related to the independent variables of the groups

\begin{tabular}{|c|c|c|c|c|c|c|c|c|c|c|c|c|}
\hline \multirow[b]{4}{*}{ BHS } & \multicolumn{6}{|c|}{ Experiment group } & \multicolumn{6}{|c|}{ Control group } \\
\hline & \multicolumn{3}{|c|}{ Pretest } & \multicolumn{3}{|c|}{ Posttest } & \multicolumn{3}{|c|}{ Pretest } & \multicolumn{3}{|c|}{ Posttest } \\
\hline & $\mathrm{N}$ & & sd & $\mathrm{N}$ & & sd & $\mathrm{N}$ & & sd & $\mathrm{N}$ & & sd \\
\hline & 9 & 7.6 & 2.1 & 9 & 3.3 & 4.1 & 9 & 6.6 & 3.6 & 9 & 6.3 & 4.5 \\
\hline SAI & 9 & 44.2 & 6.2 & 9 & 42.7 & 5.3 & 9 & 49.4 & 11.4 & 9 & 47.3 & 11.1 \\
\hline TAl & 9 & 38.3 & 9.1 & 9 & 36.0 & 7.6 & 9 & 42.3 & 4.9 & 9 & 45.4 & 9.7 \\
\hline MSPSS & 9 & 47.6 & 20.9 & 9 & 59.9 & 18.2 & 9 & 53.8 & 20.1 & 9 & 60.7 & 19.0 \\
\hline
\end{tabular}

As seen in Table 2, there were some differences between the pre-test and posttest mean points of the groups. The statistical significance of these differences was assessed with the Mann Whitney U-test and the results obtained are shown in Table 3.
As can be seen in Table 3, there was no significant difference between the study and control groups in the comparison of the pretest points for hopelessness $(U=30.00$; $p>0.05)$, state anxiety $(U=27.00 ; p>0.05)$, trait anxiety $(\mathrm{U}=30.50 ; \mathrm{p}>0.05)$, and multidimensional social support $(U=32.50$; $p>0.05)$. In the comparison of the post-test 
points, the state anxiety levels of the experiment group were significantly lower than those of the control group $(U=16.00$; $p<0.05$ ), while no significant difference was determined between the groups in respect of hopelessness $(U=21.50 ; p>0.05)$, trait anxiety $(U=31.50 ; p>0.05)$ and multi-dimensional social support $(U=38.50$; $p>0.05)$.
Findings obtained from comparisons within the groups

As seen in Table 2, there were differences between the pre-test and post-test points within both groups. To assess the statistical significance of these differences, the Wilcoxon Signed Rank test was applied and the results are shown in Table 4.

Table 3.

The results of the Mann Whitney U-test applied to the pre-test and post-test mean points of the groups

\begin{tabular}{|c|c|c|c|c|c|c|c|}
\hline \multirow{8}{*}{ 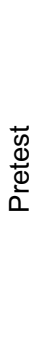 } & Variables & Groups & $n$ & $\begin{array}{l}\text { Row } \\
\text { mean }\end{array}$ & Row total & U & $p$ \\
\hline & $\mathrm{BHS}$ & $\begin{array}{l}\text { Study } \\
\text { Control }\end{array}$ & $\begin{array}{l}9 \\
9\end{array}$ & $\begin{array}{c}10.67 \\
8.33\end{array}$ & $\begin{array}{l}96.00 \\
75.00\end{array}$ & 30.00 & 0.350 \\
\hline & SAI & Study & 9 & 8.00 & 72.00 & 27.00 & 0.232 \\
\hline & & Control & 9 & 11.00 & 99.00 & & \\
\hline & TAI & Study & 9 & 8.33 & 75.00 & 30.50 & 0.353 \\
\hline & & Control & 9 & 10.67 & 96.00 & & \\
\hline & MSPSS & Study & 9 & 8.61 & 77.50 & 32.50 & 0.479 \\
\hline & & Control & 9 & 10.39 & 93.50 & & \\
\hline \multirow{8}{*}{ 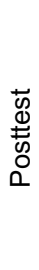 } & $\mathrm{BHS}$ & Study & 9 & 7.39 & 66.50 & 21.50 & 0.089 \\
\hline & & Control & 9 & 11.61 & 104.50 & & \\
\hline & SAI & Study & 9 & 6.78 & 61.00 & 16.00 & 0.030 \\
\hline & & Control & 9 & 12.22 & 110.00 & & \\
\hline & TAI & Study & 9 & 8.50 & 76.50 & 31.50 & 0.426 \\
\hline & & Control & 9 & 10.50 & 94.50 & & \\
\hline & MSPSS & Study & 9 & 9.28 & 83.50 & 38.50 & 0.859 \\
\hline & & Control & 9 & 9.72 & 87.50 & & \\
\hline
\end{tabular}

Tablo 4.

The Wilcoxon Signed Rank test results of the mean pre-test-post-test points of the study and control groups

\begin{tabular}{|c|c|c|c|c|c|c|c|}
\hline & Variables & $\begin{array}{l}\text { Post-test- pre-test measure- } \\
\text { ments }\end{array}$ & $\mathrm{n}$ & $\begin{array}{l}\text { Mean } \\
\text { rank }\end{array}$ & $\begin{array}{l}\text { Total } \\
\text { rank }\end{array}$ & $z$ & $\mathrm{p}$ \\
\hline \multirow{12}{*}{ 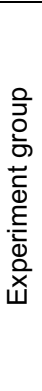 } & $\mathrm{BHS}$ & Negative rank & 8 & 4.81 & 38.50 & - & 0.057 \\
\hline & & Positive rank & 1 & 6.50 & 6.50 & 1.901 & \\
\hline & & Ties & 0 & & & & \\
\hline & SAI & Negative rank & 5 & 4.40 & 22.00 & - & 0.575 \\
\hline & & Positive rank & 3 & 4.67 & 14.00 & 0.561 & \\
\hline & & Ties & 1 & & & & \\
\hline & TAl & Negative rank & 5 & 4.40 & 22.00 & - & 0.575 \\
\hline & & Positive rank & 3 & 4.67 & 14.00 & 0.561 & \\
\hline & & Ties & 1 & & & & \\
\hline & MSPSS & Negative rank & 0 & .00 & .00 & - & 0.008 \\
\hline & & Positive rank & 9 & 5.00 & 45.00 & 2.668 & \\
\hline & & Ties & 0 & & & & \\
\hline \multirow{12}{*}{$\begin{array}{l}\text { 음 } \\
\text { 흐 } \\
\overline{0} \\
\text { 늠 } \\
\text { U }\end{array}$} & $\mathrm{BHS}$ & Negative rank & 5 & 3.90 & 19.50 & - & 0.831 \\
\hline & & Positive rank & 3 & 5.50 & 16.50 & 0.213 & \\
\hline & & Ties & 1 & & & & \\
\hline & SAI & Negative rank & 4 & 3.75 & 15.00 & - & 0.374 \\
\hline & & Positive rank & 5 & 6.00 & 30.00 & 0.889 & \\
\hline & & Ties & 0 & & & & \\
\hline & TAl & Negative rank & 5 & 3.90 & 19.50 & - & 0.352 \\
\hline & & Positive rank & 2 & 4.25 & 8.50 & 0.931 & \\
\hline & & Ties & 2 & & & & \\
\hline & MSPSS & Negative rank & 2 & 3.50 & 7.00 & - & 0.123 \\
\hline & & Positive rank & 6 & 4.83 & 29.00 & 1.542 & \\
\hline & & Ties & 1 & & & & \\
\hline
\end{tabular}

International Journal of Early Childhood Special Education (INT-JECSE), 9(2) - 2017, 81-98. 
As seen in Table 4, in the experiment group no difference was determined in respect ofhopelessness $(z=-1.901)$, state anxiety $(z=-$ $0.561)$ and trait anxiety ( $z=-0.561)$ as a result of the comparison of pre-test-post-test points $(p>0.05)$, but the multi-dimensional social support post-test points were significantly higher than the pre-test points $(z=2.668 ; p<0.05)$. In the control group, no significant difference was determined between the pre-test and post-test measurements for any of the variables.

Findings related to the PSRIF results before and after the counseling program

The PSRIF developed by the researchers aimed to determine the degree of psychological difficulties experienced by the parents related to having a child with disability. The responses given by the parents to each item were classified as a low level of difficulty at 1-3 points, a moderate level at 4-6 points and a high level at 7-10 points. The numbers and percentages of the PSRIF results of the groups in the pre-test and post-test are given in Table 5 .

As seen in Table 5, in the pre-test, the experiment group participants experienced moderate and high levels of problems in at least 8 problem areas and $11 \%-56 \%$ of the participants experienced a level of moderate or high severity in at least one of these problems. In the post-test, the rate of moderate or high severity in at least one of these problems was seen to be $11 \%-22 \%$. In the control group this rate was $22 \%-56 \%$ in the pre-test and $11 \%-44 \%$ in the post-test. A moderate or high level of difficulty was experienced by the control group in at least 10 problem areas pre-test and in 11 areas in the post-test. These results suggest that the experimental program applied was effective in meeting the needs for psychological support of the parents related to having a child with disability.

\section{Discussion}

The descriptive findings of this study of the difficulties experienced by the parents of children with disabilities and potential solutions were seen to be for the most part in parallel with the theoretical specifications of Reality Therapy. It was determined in the study what the problem areas specific to the parents of children with disabilities and what the specific markers related to these problems could be and which needs these markers could correspond to in theory (see
Table 1). Moreover, taking into consideration the statements of the participants after the application of the program, findings were obtained consistent with theoretical explanations. Reality Therapy advocates that by making choices despite all the difficulties of reality, people can meet their needs in their own behaviours and thus become self-fulfilled (Wubbolding, 2000; Ivey, Ivey, Myers, and Sweeney, 2013).

To be able to do this, the individual must first be aware of their needs (Wubbolding et al., 2004). When the statements given by the participants after the experiment were considered, it can be said that they had developed their awareness and had started to be much more functionally active compared to before the program in their relationships with their spouse, in making time for themselves, in making choices more freely and in meeting their needs for fun and power and had become happier. This awareness was stated by participant P5: "...I felt a need for freedom, and just like others, a need for love and to be loved and so I want to establish empathy and that way, everything will work out. I want to take steps to meet my needs by trying to understand the other person's needs."

It was also seen in the group counseling process that was applied that the partiicipants developed their personal awareness on the subjects of love and a feeling of belonging and freedom. In the same way, despite all the barriers to the need for power and control created by the life of a child with disability, it was possible for an individual to make choices and decisions for their personal life. The statement of participant P3 is an example of awareness of this point: "What we shared here was what we've experienced and I explained to my husband a little bit of how I felt and especially situations that made me feel upset.... When I spoke about it here I noticed that really in the end when I'm talking about my sadness, why do I seem weak, and what happens if I seem weak? In the end there is my husband. That I even thought that seems ridiculous to me now". Thus, the feedback from the experiment group participants revealed what the difficulties are of being a parent of a child with disability and how they deal with it.

The parents developed awareness despite the difficulties of having a child with disability and acted in accordance with this awareness. In other words, although the actual situation had not changed, the parents 
made more functional choices for themselves after the program compared to before. It can also be said from the statement given above that they had started to be aware of the sources of social support, to feel hope in respect of their relationships and to have reduced their anxieties on this subject. At this point it seems that signs such as hopelessness, anxiety and low social perceptions are related to the meeting the psycho logical needs which are predicted in the basis of the theory of these difficulties experienced by the parents. This suggests that the symptoms in question could be inhibiting the life of individuals in meeting the psychological needs The program developed in this study was focussed on the theoretically defined psychological needs rather than the symptoms of the parents

\section{Table 5.}

The numbers and percentages of the PSRIF results of the groups in the pre-test and post-test

\begin{tabular}{|c|c|c|c|c|c|c|c|c|c|c|c|c|c|c|c|c|c|c|c|c|c|c|c|c|}
\hline & \multicolumn{12}{|c|}{ Experiment group } & \multicolumn{12}{|c|}{ Control group } \\
\hline & \multirow{2}{*}{\multicolumn{2}{|c|}{ Low }} & \multicolumn{4}{|c|}{ Pre-test } & \multicolumn{6}{|c|}{ Post-test } & \multicolumn{6}{|c|}{ Pre-test } & \multicolumn{6}{|c|}{ Post-test } \\
\hline & & & \multicolumn{2}{|c|}{ Mod } & \multicolumn{2}{|c|}{ High } & \multicolumn{2}{|c|}{ Low } & \multicolumn{2}{|c|}{ Mod } & \multicolumn{2}{|c|}{ High } & \multicolumn{2}{|c|}{ Low } & \multicolumn{2}{|c|}{ Mod } & \multicolumn{2}{|c|}{ High } & \multicolumn{2}{|c|}{ Low } & \multicolumn{2}{|c|}{ Mod } & \multicolumn{2}{|c|}{ High } \\
\hline & $\mathrm{n}$ & $\%$ & $\mathrm{n}$ & $\%$ & $\mathrm{n}$ & $\%$ & $\mathrm{n}$ & $\%$ & $\mathrm{n}$ & $\%$ & $\mathrm{n}$ & $\%$ & $\mathrm{n}$ & $\%$ & $\mathrm{n}$ & $\%$ & $\mathrm{n}$ & $\%$ & $\mathrm{n}$ & $\%$ & $\mathrm{n}$ & $\%$ & $\mathrm{n}$ & $\%$ \\
\hline $\begin{array}{l}\text { 1. I experience conflict with my } \\
\text { spouse because of our child's } \\
\text { disability. }\end{array}$ & 5 & 56 & 2 & 22 & 2 & 22 & 7 & 78 & 1 & 11 & 1 & 11 & 5 & 56 & 2 & 22 & 2 & 22 & 6 & 67 & 1 & 11 & 2 & 22 \\
\hline $\begin{array}{l}\text { 2. I can't prevent the behav- } \\
\text { ioural problems of my child. }\end{array}$ & 3 & 33 & 4 & 44 & 2 & 22 & 4 & 44 & 4 & 44 & 1 & 11 & 3 & 33 & 4 & 44 & 2 & 22 & 2 & 22 & 5 & 56 & 2 & 22 \\
\hline $\begin{array}{l}\text { 3. When I'm in the company of } \\
\text { relatives, I'm embarrassed } \\
\text { when a problem occurs be- } \\
\text { cause of my child's disability. }\end{array}$ & 8 & 89 & 1 & 11 & & & 7 & 78 & 1 & 11 & 1 & 11 & 3 & 33 & 4 & 44 & 2 & 22 & 6 & 67 & 2 & 22 & 1 & 11 \\
\hline $\begin{array}{l}\text { 4. I'm uncomfortable because } \\
\text { of my child's behaviour when } \\
\text { I'm in crowded places such as } \\
\text { public transport, shopping } \\
\text { centres or parks. }\end{array}$ & 9 & 100 & & & & & 9 & 100 & & & & & 4 & 44 & 3 & 33 & 2 & 22 & 5 & 56 & 4 & 44 & & \\
\hline $\begin{array}{l}\text { 5. However hard I try, it feels } \\
\text { as if I have not made enough } \\
\text { time for my child. }\end{array}$ & 3 & 33 & 2 & 22 & 4 & 44 & 8 & 89 & & & 1 & 11 & 3 & 33 & 2 & 22 & 4 & 44 & 2 & 22 & 3 & 33 & 4 & 44 \\
\hline $\begin{array}{l}\text { 6. As the parent of a child with } \\
\text { disability, I don't even have } \\
\text { time to feed myself. }\end{array}$ & 9 & 100 & & & & & 9 & 100 & & & & & 8 & 89 & & & 1 & 11 & 8 & 89 & 1 & 11 & & \\
\hline $\begin{array}{l}\text { 7. I worry about who would } \\
\text { look after my child if anything } \\
\text { happened to me. }\end{array}$ & 2 & 22 & 2 & 22 & 5 & 56 & 5 & 56 & 2 & 22 & 2 & 22 & 3 & 33 & & & 6 & 67 & 4 & 44 & 1 & 11 & 4 & 44 \\
\hline $\begin{array}{l}\text { 8. Much as I love my child, } \\
\text { there are times when I wish } \\
\text { s/he hadn't been born. }\end{array}$ & 9 & 100 & & & & & 9 & 100 & & & & & 7 & 78 & 2 & 22 & & & 9 & 100 & & & & \\
\hline $\begin{array}{l}\text { 9. When constantly dealing } \\
\text { with my child, there are times } \\
\text { when I have forgotten who I } \\
\text { am. }\end{array}$ & 3 & 33 & 2 & 22 & 4 & 44 & 7 & 78 & 1 & 11 & 2 & 22 & 2 & 22 & 2 & 22 & 5 & 56 & 3 & 33 & 2 & 22 & 4 & 44 \\
\hline $\begin{array}{l}\text { 10. When my child shows } \\
\text { problem behaviour, I immedi- } \\
\text { ately feel responsible. }\end{array}$ & 5 & 56 & 3 & 33 & 1 & 11 & 7 & 78 & 1 & 11 & 1 & 11 & 5 & 56 & 2 & 22 & 2 & 22 & 4 & 44 & 3 & 33 & 2 & 22 \\
\hline $\begin{array}{l}\text { 11. I avoid putting my child in } \\
\text { the company of friends, more } \\
\text { because of the fear of a prob- } \\
\text { lem occurring than because of } \\
\text { the disability. }\end{array}$ & 7 & 78 & 2 & 22 & & & 9 & 100 & & & & & 5 & 56 & 2 & 22 & 2 & 22 & 5 & 56 & 2 & 22 & 2 & 22 \\
\hline $\begin{array}{l}\text { 12. I can't make time for my- } \\
\text { self because my child is disa- } \\
\text { bled. }\end{array}$ & 4 & 44 & 3 & 33 & 2 & 22 & 4 & 14 & 3 & 33 & 2 & 22 & 1 & 11 & 4 & 44 & 4 & 44 & 3 & 33 & 2 & 22 & 4 & 44 \\
\hline
\end{tabular}


In this context, the positive changes seen related to the hopelessness, anxiety and social support perceptions of the participants can be evaluated as indirect results associated with the focus on the basic needs predicted in Reality Therapy. Therefore, the results obtained could be a function of focussing on basic needs rather than general hopelessness, state and trait anxiety and low social support perceptions when working with the parents of children with disabilities.

When the PSRIF results of the parents and their opinions related to the counseling program were considered, it was seen that the program had helped them to make more functional decisions. In contrast, not all the quantitative results supported this. In other words, there were some noticeable relative inconsistencies between the qualitative and quantitative results of this study. Although the counseling program made no significant difference in reducing the symptoms of state and trait anxiety of the parents, the results of the PSRIF show that this was not so. For example, before the program, 5 of the participants expressed a high level of difficulty concerning the statement, "I worry about who would look after my child if anything happened to me.", whereas after the program this number had reduced to 2 . Thus, it can be said that as a result of the program, although a decrease was seen in the concerns of the parents related to the future for their child, this did not seem to be reflected in the quantitative results related to state anxiety. Nevertheless, that there was a significant decrease in state anxiety in the experiment group compared to the control group shows that the process of the group counseling program was successful in reducing anxiety in terms of quantitative results, even if only partially. This finding could be evaluated as a direct short-term effect of participation in the group process.

The difference between the statements of the parents and the quantitative results suggests that because the measurement tools used in the study were not directly developed in the framework of the problems experienced by this group, they may not reflect reality. In the results obtained in this study and in previous publications in this field which have shown that the parents of children with disabilities have a particular set of problems (Akkök, 1994; Akkök, Aşkar \& Karancı, 1992), it has been shown that the existing measurement tools are insufficient to measure the problems specific to the parents of children with disabilities. In fact, it can be said that the evaluations of the pre and post -program results of the PSRIF, which was developed to directly measure the difficulties experienced by this group, revealed in a more appropriate form the problems of the participants and the level of change. These positive results suggest that by further enriching the PSRIF, it should be brought into a form as a scale that could be used statisically in the direct measurement of the problems of this group.

One of the important findings of this study was that it revealed the necessity of increasing the awareness of parents of the difficulties that they were experiencing. Reality Therapy states that the most important condition for meeting the needs of an individual is that they must first be aware of the problem (Wubbolding et al., 2004). That the low level of social support perceptions of the parents before the program increased afterwards suggests that the awareness of the parents on this point had increased. In a short period, such as 8 weeks, it would seem to be relatively impossible for the parents to create new sources of social support. However, this result can be evaluated as related to the awareness of the parents of their perceptions of social support during the study period. In this context, it may be necessary to test any changes which may be seen on the basis of the variables in question during the time that the parents participate in the process. Therefore, further similar studies could reveal the long-term effects of this intervention in the context of Reality Therapy.

The parents of children with disabilities are known to need pyschosocial support (Sevindik, Deveci, Demirok, \& Açık, 2006; Toros, 2002). In this context, group studies provide a psychosocial environment for the individuals. Moreover, it has been reported that the counseling processes conducted in a group with parents have been more effective than individual counseling in the sense that the group process has presented a source of social support to individuals (Lewis, 1972). In this study, it can be said that by bringing individuals with similar problems together, they could be a source of support 
for each other in meeting their needs and making choices.

This can be understood from the statement of participant P4: “... although l've sometimes met people like me because we've been at the Institute because of our children, this has been different because of the psychological perspective of sharing things and now I am more peaceful and think how to spend my time more effectively. So yes, I can say I have reached my goal and I'm more comfortable now". With the group counseling process, the understanding by the group members of the mutual support means that they perceive each other as a source of social support. Thus it can be said that the group process itself could have increased the perceptions of social support at the end of the study. The need for other people to meet the needs of a person (Sommers, Flanagan \& Sommers, Flanagan, Flanagan, 2015) and to be able to make decisions freely, to be autonomous and reach self-fulfillment requires an awareness of sources of social support (Ivey, Ivey, Myers, \& Sweeney, 2013). That the parents made these positive efforts showed that they had found practical ways related to the existing situation rather than constantly worrying about the child. This finding supports the hypothesis that directly theory-based behaviours towards the event are neccessary to meet the psychological needs of an individual (Wubbolding, 2011). Consequently, with the effect of the program applied, the parents were more aware of sources of social support and they made efforts to obtain that support. This can be accepted as a sign that they could be involved in life rather than always complaining or excluding themselves from social relationships.

\section{Conclusion}

The descriptive findings obtained in the first stage of this study showed that the difficulties experienced by the parents were related to not meeting the needs of love and a feeling of belonging, power, freedom, fun and survival in parallel with the explanations related to human nature in Reality Therapy. The findings obtained in the second stage showed that the program which had been developed was statistically effective in increasing the social support perception and decreasing the level of state anxiety of the parents of children with disabilities, but there was no significant effect on the levels of hopelessness and trait anxiety. The results of the PSRIF demonstrated that the program was effective in meeting the psychological needs specific to the parents of children with disabilities. Thus, the research findings showed that in general it was appropriate to construct psychological support to be given to the parents of children with disabilities in the context of Reality Therapy.

\section{Limitations}

One of the most important limitations of this study was that no follow-up was applied. Another limitation was that a placebo group was not used in the control of the effect experienced by the group. In addition, that the group counseling process was formed of a group of mothers only as the fathers were not included for various reasons, can be evaluated as another limitation. As this was a pilot study in respect of revealing the psychological difficulties of the parents of children with disabilities in the context of Reality Therapy, further studies can be recommended to test the effect of this approach on variables other than those in this study on the parents of children with disabilities.

\section{References}

Akdoğan, R. (2016). A holistic approach to cope with depression and hopelessness for parents of special needs children. International Journal of Early Childhood Special Education (INTJECSE), 8(2), 134-150.

Akkök, F. (1994). An overview of parent training and counseling with the parents of children with mental disabilities and autism in Turkey. International Journal for the Advancement of Counseling, 17(2), 129-138.

Akkök, F., Aşkar, P., \& Karancı, N. (1992). Özürlü bir çocuğa sahip anne babalardaki stresin yordanması. Journal of Special Education, 1(2), 8-12.

Beck, A.T., Weissman, A., Lester, D., \& Trexler, L. (1974). The measurement of pessimism: The Hopelessness Scale. Journal of Consulting and Clinical Psychology, 42(6), 861- 865. 
Boyd, B. A. (2002). Examining the relationship between stress and lack of social support in mothers of children with autism. Focus on Autism and other Developmental Disabilities, 17(4), 208-215.

Case S. (2000). Refocusing on the parent: What are the social issues of concern for parents of disabled children? Disability and Society, 15, 271-292.

Corey, G. (2015). Theory and practice of counseling and psychotherapy. Nelson Education.

Coşkun, Y. \& Akkaş, G. (2009). Engelli çocuğu olan annelerin sürekli kaygı düzeyleri ile sosyal destek algıları arasındaki ilişki. Kırşehir Eğitim Fakültesi Dergisi, 10(1), 213-227.

Creswell, J. W. (2012). Research Design: Qualitative and Quantitative Approaches. London: SAGE Publication.

Çatalbaş, M., Manav, G., \& Ocakci, A. F. (2015). Kalp hastalığı olan down sendromlu çocukların ebeveynlerinin umutsuzluk düzeylerine aile merkezli hemşirelik yaklaşımı. Clinical and Experimental Health Sciences, 5(3), 154161.

Danış, M. Z. (2006). Zihinsel engelli çocuğa sahip annelerin yaşadığı duygular, çocuklarının geleceğe ilişkin düşünceleri ve umutsuzluk düzeyleri. Toplum ve Sosyal Hizmet, 17(2), 91-107.

Durak, A. (1993). Beck umutsuzluk ölçeği'nin geçerliği üzerine bir çalışma. Yayınlanmış yüksek lisans tezi. Ankara Universitesi, Sosyal Bilimler Enstitusu, Ankara.

Duran, S. \& Barlas, G. Ü. (2014). Zihinsel engelli bireylerin ebeveynlerinin öznel iyi oluş, öz duyarlık ve tükenmişlik düzeylerinin belirlenmesi. Mersin Üniversitesi Sağlık Bilimleri Dergisi, 7(3), 6979.

Eker, D. \& Arkar, H. (1995). Perceived social support: psychometric properties of the MSPSS in normal and pathological groups in a developing country. Social Psychiatry and Psychiatric Epidemiology, 30(3), 121-126.

Fortier L. M. \& Wanlass R. L. (1984). Family crisis following the diagnosis of a handicapped child. Family Relations, 33, 13-24.

http://www.jstor.org/stable/584585.

Accessed $2015 \mathrm{Jul} 21$.
Gibson, C. H. (1995) The process of empowerment in mothers of chronically ill children. Journal of Advanced Nursing, 21(6), 1201-1210.

Glasser, W. (1998). Choice theory. NY: HarperCollins.

Glasser, W. (2000). Reality therapy in action. New York, NY: Harper \& Row.

Glasser, W. (2004). A new vision for counseling. The Family Journey, 12(4), 339-341.

Glasser, W. (2005). Defining mental health as a public health problem. Chatsworth, CA: William Glasser, Inc.

Harrison, T. \& Stuifbergen, A. (2002). Disability, social support, and concern for children: depression in mothers with multiple sclerosis. Journal of Obstetric, Gynecologic, \& Neonatal Nursing, 31(4), 444-453.

Hung, J. W., Wu, Y. H., \& Yeh, C. H. (2004). Comparing stress levels of parents of children with cancer and parents of children with physical disabilities. Psycho-Oncology, 13(12), 898903.

Ivey, A. E., Ivey, M.B., Myers, J.E., \& Sweeney, T.J., (2013). Gelişimsel psikolojik danışma ve terapi: Yaşam boyu iyilik halini arttırmak. F. K. Owen, Trans Ed. Ankara: Türk PDRDER Yayınları.

Jahoda, A. \& Markova, I. (2004). Coping with social stigma: people with intellectual disabilities moving from institutions and family home." Journal of Intellectual Disability, 48(8), 719-729. http://dx.doi.org/10.1111/j.13652788.2003.00561.x.

Karadag, G. (2009). Engelli çocuğa sahip annelerin yaşadıkları güçlükler ile aileden algıladıkları sosyal destek ve umutsuzluk düzeyleri. TAF Preventive Medicine Bulletin, 8(4): 315-322.

Kroeger, K. \& Sorensen, R. (2010). A parent training model for toilet training children with autism. Journal of Intellectual Disability Research, 54(6), 556-567.

Kübler-Ross, E. (1969). On death and dying. New York, NY: Macmillan Press.

Lewis, J. (1972). Effect of group procesurewith parents of MR children. Mental Retardation, 10(6), 14-15. 
Norizan, A. \& Shamsuddin, K. (2010). Predictors of parenting stress among Malaysian mothers of children with Down syndrome. Journal of Intellectual Disability Research, 54(11), 992-1003.

Öner, N. \& Le Compte, A. (1998). Süreksiz Durumluk / Sürekli Kaygı Envanteri el Kitabı. (2. Basım) İstanbul: Boğaziçi Üniversitesi. Yayınları.

Powers, W.T (1973). Behavior: The control of perception. Chicago: Aldine.

Robey, P., Burdenski, T. K., Britzman, M., Crowell, J., \& Cisse, G. S. (2011). Systemic applications of choice theory and reality therapy: An interview with Glasser scholars. The Family Journal, 19(4), 427-433.

Seber, G. (1991). Beck umutsuzluk ölçeğinin geçerlik ve güvenirliği üzerine bir çalışma. Yayımlanmamış docentlik tezi. Anadolu Universitesi, Sağlık Bilimleri Enstitusu, Eskişehir.

Sevindik, F., Deveci, E., Demirok, A., \& Açık, Y. (2006). Engelli çocuğu olan kadınların demografik, psikosoyal ve engelli çocuğa ait doğumsal özelliklerinin incelenmesi. Sağlık ve Toplum Dergisi, 16(38), 47.

Sharf, R.S. (2012). Theories of psychotherapy and counseling: Consept and cases (5th ed.). USA: Cengage Learning Products.

Simsek, T. T., Taşçı, M., \& Karabulut, D. (2015). Desire to have other children in families with a chronically disabled children and its effect on the relationship of the parents. Turkish Archives of Pediatrics, 50(3), 163.

Soltani, A., Afshari, R., \& Bahredar, M. J. (2016). The effect of Reality Therapy on marital satisfaction of married women employed at Shiraz University of Medical Sciences. International Journal of Basic Sciences \& Applied Research, 5(3), 192-197.

Sommers-Flanagan, J. \& Sommers-Flanagan, R. (2015). Counseling and psychotherapy theories in context and practice: Skills, strategies, and techniques. John Wiley \& Sons.

Spielberger, C. D., Gorsuch, R. L., \& Lushene, R. E. (1970). The State-Trait Anxiety Inventory (Test Manual). Palo
Alto, California: Consulting Psychologists Press.

Şen, E, \& Yurtsever, S. (2007). Difficulties experienced by families with disabled children. Journal for Specialists in Pediatric Nursing, 12(4), 238-252. http://dx.doi.org/10.1111/j.17446155.2007.00119.x. Accessed 2015 Apr 11.

Taanila, A., Syrjälä, L., Kokkonen, J., \& Järvelin, M. R. (2002). Coping of parents with physically and/or intellectually disabled children. Child: Care, $\mathrm{He}$ alth and Development, 28(1), 73-86.

Toros, F. (2002). Zihinsel ve/veya bedensel engelli çocukların annelerinin anksiyete, depresyon, evlilik uyumunun ve çocuğu algılama şeklinin değerlendirilmesi. Turkiye Klinikleri Journal of Psychiatry, 3(2), 45-52.

Trigonaki, N. (2002). Parents of children with autism and five basic needs. International Journal of Reality Therapy, 21(2), 13-14.

Üskün, E. \& Gündoğar, D. (2010). The levels of stress, depression and anxiety of parents of disabled children in Turkey. Disability and Rehabilitation, 32(23), 1917-1927.

Veisson, M. (1999). Depression symptoms and emotional states in parents of disabled and disabled children. Social Behavior and Personality, 27(2), 8797.

http://dx.doi.org/10.2224/sbp.1999.27. 1.87.

Weiss, M. J. (2002). Hardiness and social support as predictors of stress in mothers of typical children, children with autism, and children with mental retardation. Autism, 6(1), 115-130.

Witcher AE. (1987). The process of grief as experienced by parents of children with handicaps. ERIC 1987:1-14. files.eric.ed.gov/fulltext/ED320369.pdf. Accessed 2016 Feb 02.

Wubbolding, R. (2000). Reality therapy for the 21st century. Philadelphia: Taylor \& Francis.

Wubbolding, R. E. (2010). Reality therapy. Washington: American Psychological Association.

Wubbolding, R. E. (2011). Reality therapy: Theories of psychotherapy series. 
Washington, DC: American Psychological Association.

Wubbolding, R. E., Brickell, J., Imhof, L., Kim, R. I. Z., Lojk, L., \& Al-Rashidi, B. (2004). Reality therapy: A global perspective. International Journal for the Advancement of Counseling, 26(3), 219-228.
Zibricky, C. D. (2014). New knowledge about motherhood: An auto ethnography on raising a disabled child. Journal of Family Studies, 20(1), 39-47. http://dx.doi.org/10.5172/jfs.2014.20.1 39.

Zimet, G. D., Dahlem, N. W., Zimet, S. G., \& Farley, G. K. (1988). The multidimensional scale of perceived social support. Journal of Personality Assessment, 52(1), 30-41. 